\title{
Technology Use Attitudes of Teachers in the Field of Special Education
}

\section{Actitudes de los profesores sobre el uso de la tecnología en el campo de la educación especial}

\author{
İbrahim Dalbudak \\ Atabey Vocational School, Isparta University of Applied Sciences, \\ ORCID ID: https://orcid.org/0000-0003-2380-803X \\ Şıhmehmet Yiğit \\ School of Physical Education and Sports Bülent Ecevit University / Zonguldak, Turkey,
} ORCID ID: https://orcid.org/0000-0002-6770-8711

*Correspondence

Email: dalbudakibo@ hotmail.com

\section{Cite as:}

Dalbudak, I., \& S1hmehmet, Y. (2021). Technology Use Attitudes of Teachers in the Field of Special Education. Propósitos y Representaciones, 9 (SPE2), e1014. Doi: http://dx.doi.org.10.20511.pyr2021.v9nSPE2.1014

(c) Universidad San Ignacio de Loyola, Vicerrectorado de Investigación, 2020. 


\section{Summary}

Information and communication technologies are extremely effective in the education of children with autism, that is, in special education, just as they are a part of our lives and affect all areas of our lives. This study was made to determine the attitudes of the teachers in the field of special education towards these technologies. 124 teachers among the teachers in the field of special education working in İzmir province participated in the study voluntarily. In the study, "Personal Information Form" and "Information and Communication Technologies Attitude Scale" developed by Günbatar (2014) to determine the level of information and communication technologies use of teachers in the field of special education were used. The data obtained were evaluated in the SPSS 23 package program. In analyzing the data, ANOVA and t-test were used for the general scale among the "Mann Whitney U" and "Kruskal Wallis 1 Way ANOVA" tests. In addition, in cases where significant differences exist, the scales at which the differences occur were determined by using "Dunn's Nonparametric Comparison" for subscales and "Tukey Post Hoc" test for general scale. As a result of the findings obtained, there is a significant difference as the age of teachers changes and according to that they have special students do sports, sports are effective on special students according to their gender, there is no significant difference according to the persistence of the knowledge that special students want to be taught while playing games, and according to their status of finding technological opportunities sufficient. As a result, we can say that as teachers' attitudes towards technology are positive, students with or without disabilities can learn information in a short time.

Keywords: Special Education, Information, Communication, Technology, Attitude, Sports.

\section{Resumen}

Las tecnologías de la información y la comunicación son extremadamente efectivas en la educación de los niños con autismo, es decir, en la educación especial, ya que son parte de nuestras vidas y afectan todos los ámbitos de nuestras vidas. Este estudio se realizó para determinar las actitudes de los docentes en el campo de la educación especial hacia estas tecnologías. 124 profesores entre los profesores en el campo de la educación especial que trabajan en la provincia de İzmir participaron en el estudio de forma voluntaria. En el estudio se utilizó el "Formulario de información personal" y la "Escala de actitud de las tecnologías de la información y la comunicación" desarrollados por Günbatar (2014) para determinar el nivel de uso de las tecnologías de la información y la comunicación por parte de los docentes en el campo de la educación especial. Los datos obtenidos se evaluaron en el programa paquete SPSS 23. En el análisis de los datos se utilizaron ANOVA y t-test para la escala general entre las pruebas "Mann Whitney U" y "Kruskal Wallis 1 Way ANOVA". Además, en los casos en que existen diferencias significativas, las escalas en las que se producen las diferencias se determinaron mediante el uso de la "Comparación no paramétrica de Dunn" para las subescalas y la prueba "Tukey Post Hoc" para la escala general. Como resultado de los hallazgos obtenidos, existe una diferencia significativa a medida que cambia la edad de los docentes y de acuerdo a que tienen alumnos especiales que hacen deporte, los deportes son efectivos en alumnos especiales según su género, no hay diferencia significativa según la persistencia del conocimiento que los estudiantes especiales quieren que se les enseñe mientras juegan, y de acuerdo a su estado de encontrar oportunidades tecnológicas suficientes. Como resultado, podemos decir que como las actitudes de los profesores hacia la tecnología son positivas, los estudiantes con o sin discapacidad pueden aprender información en poco tiempo.

Palabras clave: Educación especial, Información, Comunicación, Tecnología, Actitud, Deportes. 


\section{Introduction}

Communication and information devices have led to differentiation and development in many areas. The use of technology provides convenience in all areas of our lives. In this context, it is seen that educators working in the field of special education contribute to the field of special education in terms of using technology and making use of technology. Thanks to education, the individual gains new behaviors and changes the wrong behaviors he / she has already acquired, or he / she is enriched by reinforcing the previously acquired but missing behaviors (Kiziloluk, 2002). The existence of technology dates back to the early years of humanity. The understanding of technology at the first years of human history does not exactly coincide with the technology concept understood today. This understanding, which regards the paintings drawn in the cave as technology in the dark ages, actually regards only the tools such as computer, telephone, etc., when technology is mentioned in this century. For this reason, while a biased concept of technology could be mentioned until the industrial revolution of the 18th century, in later periods, technology has settled in our lives as a concept that is constantly affected by social regions in the hands of dominant societies and consequently affects the social sphere (Aksoy, 2003).

According to Çilenti (1988), "Educational technology is the branch of science that examines the ways of bringing individuals to the special goals of education by using accessible manpower and non-human resources with appropriate methods and techniques intelligently and skillfully, and evaluating the results based on the data of behavioral sciences on communication and learning. Communication and information exchange have been made for centuries with various tools and devices such as letter, telegraph, telephone and television. Communication technology has changed and developed in the second period of the 20th century with the continuous growth of information technologies. Today, communication is carried out by electronic devices that transfer data from one point to another. The working principle of computer systems and the transfer of data numerically with the binary number system are based on common logic. Mobile devices and computers can be given as examples of communication devices that transform digital data into a form that people can interpret and digitize such data to carry and transmit (Çeviker, 2005).

Information is the main element of technology. It is also important in the application of technology into life. The fact that our age is an information age, countries' efforts to establish superiority and competitions are related to their state of knowledge and are directly proportional (Tekin \& Ömürbek, 2004). The essence of information technologies includes computers, microelectronics and integrated circuits, communication technologies, multimedia and biotechnologies (Ege \& Sezer, 2003). With the invention of the printing press, communication technologies have continued to develop with more systematic and complex devices such as telephone and telegraph, which have taken their place in daily life with systematic mail. In time, computer technologies, which are one of the priorities of our life technologically, have also developed and took their place in the field of technology with the advances in technology and the concept of communication technologies (Turnaoğlu, 2015).

Information and communication technologies are important for the 21 st century information society, which is constantly and rapidly changing. The main reason for this is that the communication activities in daily life are provided by information and communication technologies. Communication between individuals and target audiences of organizations is preferred due to the rapid transfer of information supported by information and communication technologies. With the effect of information and communication technologies, practical fields have been in many branches such as communication with employees, public relations and customer relations, corporate communication, marketing communication. Media relations power has emerged as a natural result of technological developments. This power is extremely important for organizations in terms of internal and external communication (Uzunoğlu et al.2009). Today, tools and services such as fax, modem, telephone, computer and internet are in a location where every individual can reach easily. It is possible to mention two facilities of information technologies. These are commonization and minimization. Commonization is the collection of files, data, sounds, images with different features in the same system. Multimedia internet technologies have emerged from this union. Minimization is the miniaturization of electronic devices such as computers and telephones to a size that everyone can easily carry and use 
(Barutçugil, 2002). Educational technology is named as the branch of science where the data emerging as a result of learning and communication is the source, and which emerged with the experiment of different methods of behavioral sciences to find out what extent the result is efficient or to what extent the result serves the purposes by evaluating the situations related to education in which manpower is sufficient or the outcomes apart from manpower with certain methods and interpreting in the best way (Uşun, 2004).

The role of technology; the use of technology is a broad term, so it does not worry about increasing the academic success of students and does not focus on evaluating the educational process. In short, since there is no planning and control phase in the use of technology, its effect on the education process cannot be mentioned. However, the concept of education in technology is an effort that has a system, goal and planning stage in itself (Günüç, 2017). In the education process, technology and teacher constitute two important elements of education system. Because these two elements play a major role in the education system for students to learn. The teacher, who has undertaken different tasks in today's education system, should be able to use technology on the one hand, and teach his/her students how to use technology for learning purposes (Fidan, 2008).

Educators need to know very well that computers increase the problem solving ability of children and the importance of cooperation with children. While computers guide each individual and encourage them to be an active user in line with their own knowledge, they will also contribute to transforming the role of educator into special teaching (Pişkin, 1995). Teachers are people who follow the developments and changes that occur in our age and have to keep up with these changes. In today's global environment, teachers, like other individuals, have to struggle with the effects of events that have occurred both in the past and today. In this regard, the duty of teachers includes challenging items such as preserving the identity of the society in which they live, and preparing those individuals for the global universe. This puts extra burden on teachers. Teachers also need to develop and prepare themselves enough to carry these burdens (Güven, 2001). It is clear that curiosity emerges in various ways in the educational environment. Therefore, it is very important to keep curiosity alive to achieve effective training and results (Aktas \& Ustun, 2017). As a result, we can say that it is an important study to determine the attitudes of teachers working in special education towards information and technology and the development of disabled students.

Research Model

\section{Methodology}

In this study, descriptive and correlational survey methods, which are general survey models, were used.

Forming volunteer groups. 124 teachers among the special education teachers working in İzmir province participated in the study voluntarily.

Data collection techniques. As data collection techniques, Personal Information Form, Information and Communication Technologies Attitude Scale were used.

Personal information form. In obtaining the data, "Age", "Gender" and "Situation of Finding Technological Opportunities Sufficient", "The effect of sports on special student", "Permanent state of knowledge to be taught to special students while playing game", "Knowledge status of having special students do sports" and "Personal Information Form" prepared by the researcher regarding the demographic features were used.

Information and communication technologies attitude scale. The scale used to determine the attitudes of teachers working in the field of special education towards information and communication technologies; "Information and Communication Technologies Attitude Scale" was developed by Günbatar (2014). "ICT attitude scale" consists of 23 statements and all statements in the scale are scored positively. Each statement can be scored between 1 and 5. The lowest score that can be obtained from the scale is 23 and the highest score is 115 . The evaluation for the statements is; (1) I do not agree at all, (2) I do not agree, (3) I am indecisive, (4) I agree, (5) I completely agree. There are 5 subscales belonging to the scale;

- General ICT (items 1-2-3-4-5-6), the lowest score that can be obtained is 6 and the highest score is 30 . 
- Access to Information in Virtual Environment (7 - 8 - 9 - 10 - 11 items), the lowest possible score that can be obtained is 5 , and the highest score is 25 .

- Computer Hardware (12 - 13 - 14 - 15 items), the lowest possible score that can be obtained is 4 and the highest score is 20 .

- Software Usage (16 - 17 - 18 - 19 - 20 items), the lowest possible score that can be obtained is 5 and the highest score is 25 .

- Communication in Virtual Environment (21 - 22 - 23 items), the lowest possible score that can be obtained is 3 and the highest score is 15 .

Validity and reliability studies calculated by Günbatar (2014) are as follows: KMO value is .89, Bartlett test is 5512, and factor load values of the scale items ranges from .608 to .898. Cronbach Alpha internal consistency coefficient of the scale's sub-dimensions; General Bit Tendency is .899, Accessing Information in a Virtual Environment is .884, Computer Hardware is .881, Software Usage is .822, Accessing Information in a Virtual Environment is .761, and the whole scale is .919 . The general percentage of variance explained was 68.182 and the item test correlations of the scale ranged from 0,455 to 0,713 . It was seen that the confirmatory factor analysis confirmed the structure. According to these values, it can be said that the scale is valid and reliable.

\section{Data Analysis}

Table 1. Cronbach's Alpha Internal Consistency Coefficients of the ICT Attitude Scale and Its Subscales

\begin{tabular}{lc}
\hline Scale and Subscales & Cronbach's Alpha Value \\
\hline General ICT & 0,920 \\
Accessing Information in Virtual Environment & 0,935 \\
Computer hardware & 0,939 \\
Software Usage & 0,879 \\
Communication in Virtual Environment & 0,780 \\
\hline Attitude Scale & 0,944 \\
\hline
\end{tabular}

Cronbach's Alpha value of the ICT Attitude Scale applied to the study group according to the table was found to be $\alpha=0.944$. The scale is in the highly reliable category. When the subscales of the scale are examined, it can be evaluated that "General ICT" $(\alpha=0.920)$, "Access to Information in Virtual Environment" $(\alpha=0.935)$, "Computer Hardware" $(\alpha=0.939)$, and "Software Usage" $(\alpha=0.879)$ subscales are "highly reliable" and "Communication in Virtual Environment" $(\alpha=0,780)$ subscale is in the "acceptable" reliability category. 


\section{Findings}

When the participants were examined in terms of demographic characteristics, the following findings were reached.

Table 2. Is sport effective on special students?

Is sport effective on special students?

Frequency Percentage $(\%)$

\begin{tabular}{lcc}
\hline Yes & 90 & 72.6 \\
No & 34 & 27.4 \\
\hline Total & 124 & 100,0
\end{tabular}

$72.6 \%$ (90 people) of the participants think that sport is effective on special students while $27.4 \%$ (34 people) of them think that it is not.

Table 3. How much do you benefit from technology while having students do sports?

How much do you benefit from technology while having students do sports?
Frequency

Percentage $(\%)$

\begin{tabular}{lcc}
\hline I never profit & 17 & 13.7 \\
I benefit a little & 27 & 21.8 \\
I benefit a lot & 80 & 64.5 \\
\hline Total & 124 & 100,0
\end{tabular}

$13.7 \%$ (17 people) of the participants stated that they never benefited from technology while having students do sports, $21.8 \%$ (27 people) of them stated that they profited a little and $64.5 \%$ (80 people) of them stated that they benefited a lot.

Table 4. Can the Information Intended to Teach Special Students While Playing Games Be Taught Permanently?

Frequency Percentage (\%)

\begin{tabular}{lcc}
\hline Yes & 88 & 71.0 \\
No & 36 & 29.0 \\
\hline Total & 124 & 100,0 \\
\hline
\end{tabular}

$71.0 \%$ (88 people) of the participants said that information could be taught permanently while playing games to special students, while $29.0 \%$ (36 people) of them said that what was taught was temporary.

Analysis of ICT Attitude Scale Total Scores According To The Demographic Characteristics of Students

In the tables below, summary statistics based on demographic characteristics of the scale total scores, and p-values obtained from the "Mann Whitney U" and "Kruskal Wallis 1 Way ANOVA" tests for the subscales, and ANOVA and t-test for the general scale are given. The mean and standard deviation of each subscale are given according to the related grouped variable. In 
addition, in cases with significant differences, the scales at which the differences occur were determined by using "Dunn's Nonparametric Comparison" for subscales and "Tukey Post Hoc" test for general scale. Tests for the difference of means were carried out at $95 \%$ significance level. The p-value for variables with significant differences is shown in red in the tables.

Table 5. Distribution of Special Education Teachers by Age

\begin{tabular}{|c|c|c|c|c|c|c|c|}
\hline & \multicolumn{6}{|c|}{ Age } & \multirow{3}{*}{$\begin{array}{l}\text { p-value } \\
\text { (Sig.) }\end{array}$} \\
\hline & \multicolumn{2}{|c|}{30 and under } & \multicolumn{2}{|c|}{$41-50$} & \multicolumn{2}{|c|}{51 and above } & \\
\hline & Mean & SD & Mean & SD & Mean & $\mathrm{SD}$ & \\
\hline General ICT & 24.2258 & 2.4318 & 23.3467 & 3.3023 & 20.0556 & 5.3848 & 0.037 \\
\hline $\begin{array}{l}\text { Accessing Information } \\
\text { in Virtual Environment }\end{array}$ & 20.5161 & 3.1077 & 20.8800 & 1.9793 & 17.8889 & 4.4969 & 0.041 \\
\hline Computer hardware & 11.3226 & 4.9016 & 8.6667 & 3.9157 & 5.5000 & 2.3577 & 0.000 \\
\hline Software Usage & 20.4194 & 3.5756 & 17.7733 & 3.4896 & 14.3333 & 4.6904 & 0.000 \\
\hline $\begin{array}{l}\text { Communication in } \\
\text { Virtual Environment }\end{array}$ & 11.0968 & 1.4457 & 10.4667 & 2.5697 & 9.5000 & 2.1488 & 0.055 \\
\hline ICT Attitude Scale & 87.5806 & 8.5392 & 81.1333 & 10.9991 & 67.2778 & 13.1855 & 0.000 \\
\hline
\end{tabular}

According to the table above, the total average scores of the individuals for "communication in virtual environment" do not differ according to their ages. Total mean scores of "General ICT", "Access to information in virtual environment", "Computer hardware" and "software use" subscales and "ICT attitude scale" are inversely proportional to the ages of the individuals. As the age of the individuals increases, the total scores they obtain from the scale and subscales gradually decrease.

Table 6. Distribution of Special Education Teachers by Gender

\begin{tabular}{|c|c|c|c|c|c|}
\hline & \multicolumn{4}{|c|}{ Gender } & \multirow{3}{*}{$\begin{array}{l}\text { p-value } \\
\text { (Sig.) }\end{array}$} \\
\hline & \multicolumn{2}{|c|}{ Male } & \multicolumn{2}{|c|}{ Female } & \\
\hline & Mean & SD & Mean & SD & \\
\hline General ICT & 23.2326 & 4.8787 & 23.0123 & 2.9304 & 0.229 \\
\hline $\begin{array}{l}\text { Accessing Information } \\
\text { in Virtual Environment }\end{array}$ & 19.8605 & 3.6941 & 20.6173 & 2.4112 & 0.720 \\
\hline Computer hardware & 9.9767 & 4.7883 & 8.2840 & 4.0318 & 0.052 \\
\hline Software Usage & 18.3488 & 4.2363 & 17.7160 & 4.0627 & 0.288 \\
\hline $\begin{array}{l}\text { Communication in } \\
\text { Virtual Environment }\end{array}$ & 10.9302 & 1.9927 & 10.2469 & 2.4470 & 0.190 \\
\hline ICT Attitude Scale & 82.3488 & 15.4286 & 79.8765 & 10.3987 & 0.075 \\
\hline
\end{tabular}

According to the table above, the total scores obtained by individuals from the subscales and the ICT attitude scale do not differ according to their gender. Total mean scores of men and women are not different from each other. 
Table 7. Distribution of Special Education Teachers by the Status of Finding Technological Opportunities Sufficient

\begin{tabular}{|c|c|c|c|c|c|}
\hline & \multicolumn{4}{|c|}{$\begin{array}{c}\text { Status of Finding Technological Opportunities } \\
\text { Sufficient }\end{array}$} & \multirow{3}{*}{$\begin{array}{l}\text { p-value } \\
\text { (Sig.) }\end{array}$} \\
\hline & \multicolumn{2}{|c|}{ Yes } & \multicolumn{2}{|c|}{ No } & \\
\hline & Mean & $\mathrm{SD}$ & Mean & $\mathrm{SD}$ & \\
\hline General ICT & 22.7590 & 4.0382 & 23.7561 & 2.8441 & 0.353 \\
\hline $\begin{array}{l}\text { Accessing Information } \\
\text { in Virtual Environment }\end{array}$ & 20.3253 & 2.9759 & 20.4146 & 2.8633 & 0.412 \\
\hline Computer hardware & 8.8072 & 4.4157 & 9.0000 & 4.3127 & 0.774 \\
\hline Software Usage & 17.5542 & 3.8643 & 18.7073 & 4.5400 & 0.075 \\
\hline $\begin{array}{l}\text { Communication in } \\
\text { Virtual Environment }\end{array}$ & 10.3012 & 2.4531 & 10.8537 & 1.9819 & 0.201 \\
\hline ICT Attitude Scale & 79.7470 & 13.1240 & 82.7317 & 10.5499 & 0.321 \\
\hline
\end{tabular}

Looking at the table above, all subscales and "ICT attitude scale" total score averages of individuals do not change according to their status of finding technological opportunities sufficient.

Table 8. The Effect of Sport on Special Students

\begin{tabular}{lccccc} 
& \multicolumn{3}{c}{ Is sport effective on special students? } & \multirow{2}{*}{\begin{tabular}{c} 
No \\
\cline { 2 - 5 }
\end{tabular}} & \multicolumn{3}{c}{ Yes } & \multicolumn{2}{c}{ Nolue } \\
\cline { 2 - 5 } & Mean & SD & Mean & SD & \\
\hline General ICT & 23.0667 & 3.5689 & 23.1471 & 4.0982 & 0.634 \\
$\begin{array}{l}\text { Accessing Information in } \\
\text { Virtual Environment }\end{array}$ & 20.5222 & 2.8333 & 19.9118 & 3.1658 & 0.326 \\
$\begin{array}{l}\text { Computer hardware } \\
\text { Software Usage }\end{array}$ & 8.8222 & 4.2547 & 9.0000 & 4.7097 & 0.966 \\
$\begin{array}{l}\text { Communication in Virtual } \\
\text { Environment }\end{array}$ & 17.8111 & 3.9997 & 18.2647 & 4.4606 & 0.401 \\
\hline ICT Attitude Scale & 10.4556 & 2.4132 & 10.5588 & 2.0625 & 0.995 \\
\hline
\end{tabular}

The total score averages obtained from all subscales and the ICT attitude scale of those who stated that sport was effective on special students and those who stated that it was not, are not different from each other. 
Table 9. The Permanence of the Information Intended to be taught by Special Education Teachers while playing games.

\begin{tabular}{|c|c|c|c|c|c|}
\hline & \multicolumn{4}{|c|}{$\begin{array}{c}\text { Can the information intended be taught to special } \\
\text { students while playing games be taught } \\
\text { permanently? }\end{array}$} & \multirow{3}{*}{$\begin{array}{l}\text { p-value } \\
\text { (Sig.) }\end{array}$} \\
\hline & \multicolumn{2}{|c|}{ Yes } & \multicolumn{2}{|c|}{ No } & \\
\hline & Mean & SD & Mean & SD & \\
\hline General ICT & 23.3750 & 3.5664 & 22.3889 & 3.9876 & 0.229 \\
\hline $\begin{array}{l}\text { Accessing Information in } \\
\text { Virtual Environment }\end{array}$ & 20.6136 & 2.7892 & 19.7222 & 3.1947 & 0.120 \\
\hline Computer hardware & 8.8977 & 4.2400 & 8.8056 & 4.7196 & 0.706 \\
\hline Software Usage & 17.9205 & 4.0349 & 17.9722 & 4.3719 & 0.943 \\
\hline $\begin{array}{l}\text { Communication in Virtual } \\
\text { Environment }\end{array}$ & 10.5568 & 2.2430 & 10.3056 & 2.5050 & 0.823 \\
\hline ICT Attitude Scale & 81.3636 & 12.0622 & 79.1944 & 13.1384 & 0.384 \\
\hline
\end{tabular}

There is no significant difference between the subscale and ICT attitude scale total scores of those who said yes and those who said no to the question "Can the information intended be taught to special students while playing games be taught permanently?"

Table 10. Special Education Teachers' Status of information about having special students do sports.

\begin{tabular}{|c|c|c|c|c|c|c|}
\hline \multicolumn{6}{|c|}{$\begin{array}{l}\text { How much is your information about having special } \\
\text { students do sports? }\end{array}$} & \multirow{3}{*}{$\begin{array}{l}\text { p-value } \\
\text { (Sig.) }\end{array}$} \\
\hline \multicolumn{2}{|c|}{$\begin{array}{l}\text { I have no } \\
\text { information }\end{array}$} & \multicolumn{2}{|c|}{$\begin{array}{l}\text { I have some } \\
\text { information }\end{array}$} & \multicolumn{2}{|c|}{$\begin{array}{l}\text { I have a lot of } \\
\text { information }\end{array}$} & \\
\hline Mean & SD & Mean & SD & Mean & SD & \\
\hline 22.7895 & 3.1194 & 23.2105 & 3.9304 & 22.9655 & 3.5404 & 0.746 \\
\hline 20.8947 & 2.2084 & 20.2105 & 3.0954 & 20.3793 & 2.9327 & 0.390 \\
\hline 8.6842 & 4.8310 & 9.1579 & 4.5403 & 8.2414 & 3.5822 & 0.817 \\
\hline 18,000 & 2.5819 & 18.3553 & 4.1591 & 16.7931 & 4.6933 & 0.161 \\
\hline 9.8947 & 2.4012 & 9.9310 & 2.2189 & 10.8421 & 2.2865 & 0.033 \\
\hline
\end{tabular}

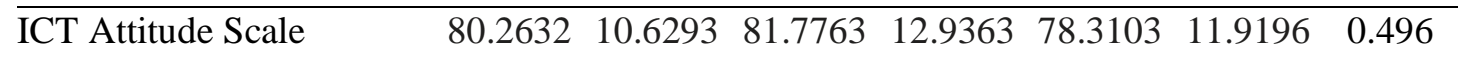

The "communication in virtual environment" subscale total scores of individuals increase as their information about having special students do sports increases. The more information is, the higher the subscale has a total score. For all other subscales and ICT attitude scale, information about having the students do sports has no effect on total scores. 


\section{Discussion and Conclusion}

Technologically, many innovations are now among the indispensables of our lives and as a natural result of this, the use of technologies by all people is not a luxury but a necessity. In the face of the unprecedented rapid change and transformation of technology in society, educational institutions are undoubtedly among the systems that are affected and have affected in this change (Taşkın, 2018). The introduction of technology in all areas of our lives has brought new teaching models together (Alaeddinoğlu \& Kalkavan, 2019). Therefore, teachers' technology acceptance and use attitudes need to be positively high.

According to the study we have done, the total average score of "communication in virtual environment" of the people does not differ according to the age variable. $(p>0.05)$ while "General ICT", "Access to information in virtual environment", "Computer hardware" and "software usage" subscales and "ICT attitude scale" total mean scores are inversely proportional to the ages of the individuals. As the age of the individuals increases, the total scores they obtain from the scale and subscales gradually decrease. ( $\mathrm{p}<0.05$ ). Romero et al. (2013) found a difference between the use of information and communication technology in students born before 1982 according to age. Kara (2010) concluded in his study that the attitude towards learning differs significantly according to the professional experience and age of the individual. We can say that age has an effect on technology usage.

In the research we have done, the total scores obtained from the ICT (Information and Communication Technologies) attitude scale and subscales do not differ according to gender. Total mean scores of men and women are not different from each other ( $p>0.05)$. Considering the gender status, Çelik and Bindak (2005) concluded in their study that the difference between male and female teachers' attitudes towards computers was not statistically significant. As a result of the research conducted by Cambaz (1999), teachers' computer attitudes did not differ according to gender. Torkzadeh and Dyke (2002) could not find a significant difference between the use of technology and the gender in their study. Sabır (2014) made a different conclusion in his study, and it was concluded that male pre-service teachers' attitudes were higher in terms of computer hardware. The fact that the use of information and communication technologies does not differ in gender dimension can be an indicator of the existence of the concept of social equality (Berkyürek, 2008).

Considering the results of the study, all subscales and "ICT attitude scale" total score averages of the individuals do not change according to their status of finding technological opportunities sufficient ( $p>0.05$ ). In other words, we can say that the technology opportunities in schools are insufficient to ensure the development of disabled or non-disabled students. Therefore, it can be stated that the training of the student will extend. In the study conducted by Çağlltay et al. (2001), it was found that the number of computers in schools was insufficient and the curriculum was not suitable for them. He found that if these deficiencies of the teachers are eliminated, the acceptance of technology and the use of technology in the classrooms will increase.

In our study, the average scores obtained from all subscales and ICT attitude scale of people who stated that sport was effective on special students and those who stated that it was not, are not different from each other ( $p>0.05$ ). There is no difference between the people who stated that sports was effective on special students and those who stated that it was not. As a result of many studies, it has been explained that sports are extremely effective on disabled or non-disabled individuals. Sport connects individuals to life and has them socialize with other people and creates people who can look at life from a different perspective. Thanks to sport, we can teach many things that we do not teach children. Children can learn information quickly and permanently. Thanks to sport, they can look at life differently.

In the study carried out, there is no significant difference between the subscale and ICT attitude scale total mean scores of those who said yes and those who said no to the question "Can the information desired to be taught to special students while playing can be taught permanently?" (p>0.05). In the studies, the behaviors desired to be taught to children can be taught through games. They learn difficultly a behavior that they would like to be taught normally. The game is extremely effective in educating students with disabilities. A normal behavior desired to be taught can be taught without getting bored thanks to the game. Thanks to the game, everything that is 
desired to be given in a short time is learned and becomes permanent. We can say that game is extremely effective for both the physical and mental development of the child.

The "communication in virtual environment" subscale total scores of individuals increase as their knowledge about having special students do sports increases. The more knowledge there is, the higher the subscale has a total score $(\mathrm{p}<0.05)$. For all other subscales and ICT attitude scale, the knowledge about having special students do sports has no effect on total scores ( $p>0.05$ ). Sport is important for every living thing, but it is more important for people with disabilities. We can say that as the knowledge of the teachers who have the students do sports increases, the perspective of teachers changes and the lessons progress in a healthier way. The more teachers use technology and the more their knowledge about sports increases, the more they have disabled students do sports. Teachers are required to use educational technologies at least as much as the technological devices they actively use, and to combine technology with field education and present it to their students by supporting them with pedagogical elements (Efe, 2011). In other words, teachers should use technological devices as much as possible, and they should offer sports opportunities to students with disabilities by combining technology with field education and supporting them with pedagogical elements. Thus, the disabled students are given the desired sport.

As a result, since technology is extremely important for all teachers, teachers should be made aware of the benefits of technology use and apply what they learn from technology in their curriculum. In this way, we can easily teach students the desired information.

\section{References}

Aksoy, H.H. (2003). "An Analysis of Technology Usage and Its Effects in Educational Institutions". Education Science Society, 4-23.

Aktas, N., \& Ustun, U.D. (2017). The measurement of curiosity of teacher candidates: a study based on breadth and depth of interest. Advanced Education (7), 33-36.

Alaeddinoglu, V., \& Kalkavan, A. (2019). Assessment of Sports Item in Cartoons Broadcasted on Trt Channels, Social Sciences Studies Journal (SSSJournal), Vol 5, issue 41, p: 41574173

Barutçugil, G. (2002). Information Management Career Publications, Istanbul: 26.

Berkyürek, İ. (2008). A Study on the Use of Information and Communication Technologies by Science and Technology Teachers-Bolu Province Case. Master Thesis, Abant İzzet Baysal University, Institute of Social Sciences, Bolu.

Cambaz, H. (1999). Evaluation of Teachers 'and Students' Attitudes and Concerns towards Computer in Teaching-Learning Process. Yüksek Lisans Tezi, Marmara Üniversitesi, Eğitim Bilimleri Enstitüsü, İstanbul.

Çağıltay, K., Çakıroğlu, J., Çağıltay, N. \& Çakıroğlu, E. (2001). Teachers' views on computer use in teaching. Hacettepe University Journal of Education, 21, 19-28.

Çelik, H.C \& Bindak, R. (2005). Investigation of the Attitudes of Teachers Working in Primary Schools towards Computer According to Various Variables. İnönü University Journal of Education, 6 (10), 27-38.

Çeviker, A. (2005). Historical Development of Information and Communication Technology in the Framework of the New Economy and Turkey. Doctoral Thesis, Marmara University, Institute of Social Sciences, Istanbul.

Çilenti, K. (1988). Educational technology and teaching. (3. Baskı). Ankara: Kadığlu Printing House.

Efe, R. (2011). Science student teachers and educational technology experience, intentions and value. Educational Technology \& Society, 14 (1), 228-240.

Ege, İ. \& Sezer, S. (2003). Use of Information Technologies and Academic Productivity: The Case of Erciyes University. II. National Information Economy and Management Congress. Derbent-İzmir.

Fidan, K.N. (2008). Teachers' Views on the Use of Tools and Equipment in Primary Education. Ankara University Theoretical Education Science Journal 1, Ankara. 
Günüç, S. (2017). Theoretical Bases of Technology Integration in Education. Anı Publishing, Ankara: 13

Günbatar, M.S. (2014). Developing an Attitude Scale Towards Information and Communication Technologies. Ahi Evran University Journal of Kurşehir Education Faculty (KEFAD) Vol 15: 121-135.

Trust, İ. (2001). The International Dimension of Teacher Training. Unesco 45. International Education Congress. Journal of National Education. (150), 20-27.

Kara, A. (2010). "Development of Attitudes Towards Learning ", Electronic Journal of Social Sciences, $\mathrm{p}: 32$.

Kizıloluk, H. (2002). Introduction to the teaching profession. Ankara: Mikro Publications.

Piskin, Ü. (1995). Investigation of the Effects of Educator Guidance with Computer on Concept Education of 5-8 Years Old Children with Autism. PhD Thesis. Hacettepe University, Institute of Health Sciences, Ankara.

Romero, M., Guitert, M., Sangra, A., \& Bullen, M. (2013). Do UOC students fit in the net generation profile? An approach to their habits in ICT use. International Review of Research in Open and Distance Learning, 14, 158-181.

Patience, OD (2014). Analysis of Information Searching Behaviors on the Internet. Bahçeşehir University, Institute of Science, İstanbul.

Taşkın, HB (2018). Analysis of Teachers' Acceptance and Intention to Use Information and Communication Technologies According to Various Variables. Master Thesis, Y1ldiz Technical University, Institute of Science, Istanbul.

Tekin, M. \& Ömürbek, NU (2004). Technological cooperation and Automotive Sector Applications in Global Competitive Environment. Selçuk University Publishing House, Konya: 151.

Turnaoğlu, M. (2015). Effects of Developments in Communication Technology on Commercial Relations and Reflections on the New Turkish Commercial Code. Master Thesis, Istanbul Commerce University, Institute of Social Sciences, Istanbul.

Uşun, S. (2004). Fundamentals of Computer Assisted Instruction. 2nd ed. Ankara: Nobel Publishing.

Uzunoğlu, E, Onat, F, Alikılıç Ö. A. \& Çakır S.Y. (2009). Corporate Communication in the Internet Age. Say Publications, Istanbul: 12-14. 